\title{
Tradisi Barzanji, Antara Sakral dan Profan di Masjid Raya Campalagian
}

\author{
Idham Hamid \\ UIN Sunan Kalijaga Yogyakarta \\ idhamhamid56@gmail.com
}

\begin{abstract}
ABSTRAK
Ada banyak cara atau metode memanggil orang-orang untuk melaksanakan panggilan ibadah. Salah satunya adalah tradisi barazanji yang rutin dilaksanakan setiap malam Jum'at setelah shalat magrib berjamaah. Agenda rutin ini merupakan praktek yang telah turun-temurun dititiskan oleh para ulama-ulama sebagai upaya mensyi'arkan Islam. Hal ini dalam rangka untuk memudahkan masyarakat dalam mempraktekkan konsep ibadah ritual maupun sosial. Ada yang berbeda ketika praktek tersebut kita bandingkan dengan apa yang umum terjadi di daerah lainnya. Di tengah pembacaan teks barzanji, terdapat momen sakral yang disebut mahallul qiyam (asarakah), di mana para peserta diwajibkan berdiri dengan sikap merendahkan hati. Ungkapan simbolik ini terangkum dengan hadirnya buahbuahan seperti pisang, langsat, mangga, dan rambutan, sebagai salah satu bagian terpenting dalam kegiatan tersebut dan buah akan dibagikan kepada para jama'ah setelah pembacaan doa barzanji. Tidak ada yang mengetahui persis kapan tradisi ini dimulai dan mengapa harus buah yang dihadirkan dalam praktek tersebut. Namun, yang terpenting dari tradisi ini, terselip nilai-nilai simbolisasi yang memberikan kesan yang luhur bahwa para ulama-ulama dahulu dalam memberikan akses terbuka untuk menyampaikan ajaran Islam, tidak hanya dengan cara metode skriptual atau fundamentalis, juga tidak mengabaikan apsek sosial masyarakat yang mengitarinya, tetapi keduanya menyatu dalam bingkai budaya dan nilai spiritual Islam.
\end{abstract}

\section{Keywords: Sakral, Simbol, Tradisi, Barzanji}

\section{PENDAHULUAN}

Hadis bagi umat Islam merupakan suatu yang penting dimana di dalamnya terungkap berbagai tradisi yang berkembang pada masa Rasulullah saw. Tradistradisi yang hidup pada masa kenabian tersebut mengacu pada diri Rasulullah saw. sebagai utusan Allah swt. Di dalamnya syarat akan berbagai ajaran Islam karenanya keberlanjutannya terus berjalan dan berkembang hingga sekarang seiring dengan kebutuhan manusia. Adanya keberlanjutan tradisi itulah sehingga umat manusia di zaman sekarang ini bisa memahami, merekam dan melaksanakan tuntunan ajaran Islam yang sesuai dengan apa yang telah dicontohkan Rasulullah 
Muhammad saw. ${ }^{1}$ Rasulullah saw. sebagai suri teladan bagi umatnya, memberikan ketertarikan sendiri bagi setiap invidu atau kelompok untuk senantiasa menghidupkan dan melestarikan sunnah Rasulullah saw.

Salah satu bentuk upaya melestarikan sunnah Rasulullah saw. adalah tradisi barzanji di Masjid Raya Campalagian. Agenda tersebut rutin dilaksanakan setiap sekali dalam seminggu tepatnya pada malam Jum'at setelah shalat magrib berjamaah. Ada yang berbeda dalam praktek tersebut ketika kita bandingkan dengan apa yang lazim terjadi di daerah lainnya. Di tengah pembacaan itu, terdapat momen sakral yang disebut mahallul qiyam (asarakah), di mana para peserta diwajibkan berdiri dengan sikap merendahkan hati. Selain itu, uniknya setelah pembacaan doa barzanji, buah atau makanan yang telah dibacakan doa, akan dibagikan kepada para jama'ah yang hadir pada saat kegiatan berlangsung.

Kehadiran sajian buah-buahan dan makanan seperti pisang sebagai menu utamanya, langsat, mangga, dan rambutan, yang disajikan ketika pembacaan barzanji berlangsung. Hal ini merupakan ungkapan simbolisasi yang sakral terhadap nilai-nilai yang terkandung dalam tradisi barzanji dan sebagai perwujudan rasa cinta dan penghormatan kepada Nabi Muhammad saw. Tidak ada yang mengetahui persis kapan tradisi ini dimulai dan mengapa harus buah yang dihadirkan dalam praktek tersebut. Namun, yang terpenting dari tradisi ini terselip nilai-nilai simbolik yang memberikan kesan yang luhur bahwa para ulama-ulama dahulu memberikan akses terbuka untuk menyampaikan sumber-sumber keagamaan. Tradisi barzanji di Masjid Raya Campalagian tidak seperti pada umumnya yang terjadi di tempat-tempat lain. Hal ini disebabkan karena sejarah panjang yang mengitarinya yang telah diukir oleh ulama-ulama dalam upaya pemurnian dari kepercayaan masyarakat dari unsur paganisme.

Dari uraian di atas, yang akan menjadi pembahasan dalam penelitian ini adalah mengulas sekilas bentuk living hadis dalam praktek tradisi barzanji di Masjid Raya Campalagian dengan melihat fenomena melalui simbol-simbol.

${ }^{1}$ M. Alfatih suryadilaga, "Model-model Living Hadis" dalam Sohiron Syamsuddin (ed.) Metodologi Penelitian Living Qur'an dan Hadis (Yogyakarta; TH Press, 2007), h. 105. 
Masalah penelitian dalam penelitian ini akan dirumuskan dalam dua pertanyaan. Pertama, bagaimana masyarakat memaknai simbol-simbol dalam tradisi barzanji di Masjid Raya Campalagian?. Kedua, apa tujuan simbol-simbol dihadirkan dalam praktek tersebut?.

\section{Kedudukan Barzanji di Kalangan Masyarakat Indonesia}

Bait-bait syair Arab dalam Barzanji, ${ }^{2}$ secara garis besar mengandung bacaan untuk memuji Allah swt. dan Rasulullah saw., ${ }^{3}$ sehingga keduanya termasuk ke dalam syair bergenre al-madḥ al-nabawi (puji-pujian kepada nabi). ${ }^{4}$ Dalam sastra Arab, madah merupakan syair pujian kepada seorang tokoh atau kaum dikarenakan kebaikan akhlak dan keindahan fisiknya, ${ }^{5}$. Maka jika objek pujiannya adalah sosok Rasulullah saw., tentu motivasinya lebih bersifat religius (keagamaan) dan bukan duniawi, karena rasa cinta yang mendalam kepada beliau, harapan mendapat ridha Allah dan balasan di akhirat.

Barzanji menjadi sebuah genre syair Arab yang dikenal populer di beberapa wilayah di Indonesia hingga sampai ke pelosok daerah, dan dipahami sebagai lantunan ritual Islam (Islamic devotional songs) dalam berbagai terminology, seperti salawat, marhaban, qasidah maupun dengan sentuhan nyanyian sufistik. ${ }^{6}$ Martin van Bruinessen menyebutkan bahwa barzanji merupakan teks keagamaan yang paling populer di seluruh Nusantara yang diadaptasi dari pengaruh ulama Kurdi di Indonesia, dengan popularitas satu tingkat di bawah al-Qur'an.

Kendati disebut kitab atau buku maulid, ia tidak hanya dibaca pada hari kelahiran Nabi saw., namun juga pada berbagai acara tradisional lainnya, seperti

${ }^{2}$ Ditulis oleh Zainuddin Ja'far ibn Hasan ibn ‘Abd al-Karim/w.1177 H.

${ }^{3}$ Roger Allen, An Introduction to Arabic Literature (Australia: Cambridge University Press, 2003), h. 62 dan 87.

${ }^{4}$ Fadlil Munawwar Manshur, "Polemik Pemaknaan Kasidah Burdah al-Bushiry: Kajian Estetika Negatif", Jurnal Adabiyyat, vol. xi, no, 2, Desember 2012, h. 168-169.

${ }^{5}$ Umar Bukhory, Tradisi Membaca Syair Arab Masyarakat Muslim Pamekasan: Studi Estetika Resepsi atas Barzanji dan Burdah di Pondok Pesantren, Disertasi (Yogyakarta: Pascasarjana UIN Sunan Kalijaga, 2018), h. 53.

${ }^{6}$ Anne K. Rasmussen, Women, the Recited Qur'an and Islamic Music in Indonesia (California: University of California Press, 2010), h. 180-181. 
dalam acara yang mengikuti daur kehidupan manusia semacam aqiqah, atau dalam situasi ktiris sebagai bagian dari ritual mengusir setan, atau dalam wiridan berjama' ah. Bahkan, van Bruinessen menyebutkan tidak ada orang Indonesia yang tidak pernah menghadiri pembacaan barzanji setidaknya beberapa kali selama hidupnya. Sementara kata "barzanji" sendiri merupakan nama keluarga ulama dan syaikh tarekat yang paling berpengaruh di Kurdistan Selatan. ${ }^{7}$ Tidak ditemukan catatan yang jelas tentang kapan barzanji masuk untuk pertama kalinya ke Indonesia. Namun, jika pandangan van Bruinessen dirujuk, bahwa barzanji merupakan bagian dari pengaruh ulama Kurdi dan Tarekat Qadariyah di Indonesia, maka diperkirakan bahwa barzanji telah masuk ke wilayah Nusantara ini sekitar pertengahan abad ke-17 M, menjelang wafatnya sang pengarang dan bersamaan dengan peran aktif ulama Kurdi dalam proses Islamisasi di Indonesia. ${ }^{8}$

\section{Sekilas Tradisi dan Kepercayaan di Tanah Mandar}

Jauh sebelum Islam masuk ke Mandar, agama Hindu dan kepercayaan lokal merupakan bagian dari keyakinan dan teras budaya Mandar. Sejak kedatangan Islam, agama ini kemudian menjadi bagian prinsipil dalam keseluruhan aspek kehidupan mayoritas orang Mandar. Ketika membicarakan orang Mandar, maka harus pula membaca Islam sebagai landasan agama dan kepercayaan mereka. Islam telah menyatu dalam struktur sosial dan budaya Mandar. Ismail menyebutkan bahwa Islam telah bersintesa dalam budaya orang Mandar. ${ }^{9}$

Penerimaan Islam bagi orang Mandarpun, disebabkan oleh beberapa alasan. Pertama, telah terdapat benih-benih religi pada masyarakat, seperti kepercayaan dan praktik ritual. Kedua, ajaran Islam dipandang memiliki kemiripan dengan kepercayaan lama yang mereka anut, seperti makhluk halus dan kekuatan gaib.

\footnotetext{
${ }^{7}$ Martin van Bruinessen, Kitab Kuning, Pesantren dan Tarekat; Tradisi-tradisi Islam di Indonesia (Cet.III; Bandung: Mizan, 1999), h. 88-89.

${ }^{8}$ Masykuri Abdurrahman, Burdah Imam al-Bukhari; Kasidah Cinta dari Tepi Nil untuk Sang Nabi (Pasuruan: Pustaka Sidogiri, 2009), h. ix.

${ }^{9}$ Arifuddin Ismail, Unsur-Unsur Islam dalam Ritual Nelayan Mandar di Pambusuang Kab. Polewali Mandar Sulawesi Barat. Dalam Majalah Walasuji vol 5, No. 2, Desember 2014, h. 4.
} 
Ketiga, nilai-nilai ajaran Islam dipandang sebagai kebenaran. ${ }^{10}$ Berdasarkan kenyataan tersebut, Ismail berupaya menyampaikan bahwa inkulturasi Islam dalam peri-kehidupan masyarakat dapat teraplikasi dengan baik, tanpa memerlukan pemaksaan atau konflik, sebagaimana yang terjadi pada beberapa kebudayaan lain di negeri ini. Ketika Islam telah terinternalisasi dalam kehidupan masyarakat mandaar maka praktik-praktik lokal dapat tetap dihadirkan di tengahtengah masyarakat Mandar yang memeluk agama Islam.

\section{Simbol sebagai Yang Sakral (the sacred)}

Memahami sebuah agama dalam pandangan Mircea Eliade tidak boleh bersifat reduksionis. Karena itu, fenomena agama harus ditangkap berdasarkan tahapan-tahapan pertumbuhannya dan hanya mungkin dilaksanakan, jika agama dipahami sebagai sesuatu yang religius. Maka, seluruh unsur agama menjadi unik dan tidak dapat direduksi, sehingga ia dipandang sebagai dimensi sakralitas agama. $^{11}$

Sesuatu "yang sakral" senantiasa mewujudkan dirinya sendiri dalam realitas dan berbeda dengan realitas natural dan "yang profan". Maka hal-hal yang berada dibalik pengalaman natural manusia tidaklah mudah dirupakan dalam wujud bahasa.

Hal inilah yang disebut Eliade dengan istilah hierophany (wujud realitas sakral), karena sejarah agama-agama sejak era primitif hingga perkembangan, sebagian besar dipenuhi oleh sejumlah perwujudan dari realitas sacral. Pada masyarakat pra-modern dan primitive, sakralitas adalah kekuatan sekaligus realitas. Pengertian ini terbawa hingga era modern dengan memahami kekuatan sakral sebagai keabadian dan kemakbulan. ${ }^{12}$ Sayangnya, setiap penampakan

\footnotetext{
${ }^{10}$ Sastri Sunarti, Kosmologi Laut dalam Tradisi Lisan Orang Mandar di Sulawesi Barat, Jurnal Aksara vol 29, No. 1, Juni 2017, h. 37.

${ }^{11}$ Daniel L. Pals, Seven Theories of Religion; Tujuh Teori Agama Paling Komprehensif, Inyiak Ridwan Muzir \& M. Syukri terj., (Cet. II; Yogyakarta: IRCiCoD, 2012), h. 230.

${ }^{12}$ Mircea Eliade, The Sacred and the Profane; the Nature of Religion (New York: A Harvest Books,t.t), h. 10-12.
} 
hierophany, selalu memunculkan esensi koeksistensial yang kontradiktifparadoksal, eternalitas dengan non-eternalitas, absolut-relatif dan lain-lain. ${ }^{13}$

Sebagai sesuatu yang sakral, teks agama merupakan wilayah supernatural, extra ordinary, tak mudah terlupakan dan teramat penting. Keabadiannya terkandung pada kepenuhan substansi dan realitas. Konsep "Yang Sakral" dipahami sebagai sumber sekaligus pusat dari agama, ${ }^{14}$ yang menarik untuk digali lebih lanjut.

Penelitian tentang tradisi barzanji di Masjid Raya Campalagian ini sesungguhnya termasuk dalam ranah tindakan keragamaan populer masyarakat umum yang bersumber dari tradisi dan proses kulturasi budaya dan ajaran Islam, sehingga lebih menampakkan dimensi performatifnya. Sehingga, tatkala kualitas tampilan, seperti bunyi, pengulangan, gerakan, pakaian, sampai pada tampilan simbol-simbol, memuat pesan-pesan tertentu yang nampak secara signifikan dan efektif. Belum lagi, konteks penerapannya dalam kehidupan sehari-hari yang mengandung pedoman, inspirasi, penghibur hati dan pengetahuan untuk menemukan kebutuhan personal terpenting dalam semua jenisnya, sehingga dampaknya menjadi signifikan.

Olehnya itu, konteks sakralitas pada tradisi barzanji dapat meluas ke aspekaspek agama yang bersifat pragmatik-performatif sekaligus antropologi, seperti ranah-ranah liturgy, doa, arsitektur, seni, alat dan perkakas, tumbuhan dan makanan, gaya hidup, bahasa, dan sistem kekeluargaan. Karena hal tersebut menjadi instrumen, di mana kehidupan akan mendapatkan makna dan nilai, serta di mana dunia dan seluruh atributnya tercipta dan ditemukan. ${ }^{15}$

\section{Simbolisasi dalam Tradisi Barzanji di Masjid Raya Campalagian}

\footnotetext{
${ }^{13}$ Mircea Eliade, Pattern in Comparative Religion, Rosemary Sheed trans., (New York: The University of Nebraska Press, 1996), h. 29. h. 256 .

${ }^{14}$ Daniel L. Pals, Seven Theories of Religion; Tujuh Teori Agama Paling Komprehensif,

${ }^{15}$ Nyoman Kutha Ratna, Antropologi Sastra; Peran Unsur-unsur Kebudayaan dalam Proses kreatif (Yogyakrata: Pustaka Pelajar, 2011), h. 9-11
} 
Adanya simbol-simbol yang sakral maupun profan dalam suatu komunitas masyarakat menurut Eliade tidak tiba-tiba muncul begitu saja tanpa didahului oleh sebab tertentu. Dia menyebutkan bahwa, ada satu saat dalam kehidupan manusia, sebagian besar, mereka pernah merasakan suatu hal yang luar biasa dan sangat kuat. Mereka sangat terpukau oleh suatu realitas yang sama sekali berbeda dengan diri mereka sendiri, yakni sesuatu yang misterius, mengagumkan, dahsyat, dan teramat indah. Itulah pengalaman tentang "yang suci" satu perjumpaan dengan Yang Sakral. Kekuatan sakral berarti keseluruhan realitas, dan pada saat yang sama adalah keabadian dan kedahsyatan. Jadi, mudah dipahami kenapa manusui punya hasrat besar agar bisa bersatu dengan realitas guna meraih kekuatan-Nya. ${ }^{16}$

Dalam praktek tradisi barzanji di Masjid Raya Campalagian terdapat beberapa unsur-unsur yang dijadikan siombolisasi sebagai hakikat suci yang demilikinya dan melekat di dalamnya nilai-nilai yang sakral. Faktor inilah yang memberi dampak pada langgengnya fenomena tradisi barzanji ini sehingga dapat tetap eksis sampai saat ini. Unsur-unsur tersebut tercakup dalam beberapa poin penting di bawah ini:

\section{a. Buah-buahan}

Suku Mandar merupakan salah satu suku, di mana masyarakatnya masih memegang teguh tradisi dan budaya yang terlukis dalam ranah sosial mupun spiritual. Hal ini tergambar dalam tradisi barzanji yang dilaksanakan pada malam jum'at di Masjid Raya Campalagian. Sebagaimana kebiasaannya, masyarakat Kampung Masigi' ${ }^{17}$ dalam melaksankan kegiatan-kegiatan yang bernuansa ritual keagamaan seringkali menghadirkan simbol-simbol dalam setiap acaranya. Khusus dalam praktek barzanji ini, yang ditampilkan adalah buah-buahan berupa; pisang, mangga, langsat, dan rambutan. Adapun menu wajid yang hadir dalam kegiatan

\footnotetext{
${ }^{16}$ Mircea Eliade, The Sacred and the Profane; the Nature of Religion, h. 12-13.

${ }^{17}$ Penyebutan "kampung masiji" dinisbahkan kepada masyarakat yang mendiami wilayah sekitaran Masjid Raya Campalagian.
} 
ini adalah buah Pisang Uli. Kehadirannya bukan tanpa alasan, menurut beberapa narasumber mengatakan bahwa:

Adanya pisang ini merupakan upaya ulama-ulama dahulu untuk memanggil orang-orang agar datang untuk shalat. Juga karena pisang merupakan makanan yang populer di masyarakat pada saat itu. ${ }^{18}$

Pisang tidak pernah alpa dalam kegiatan keagamaan di masyarakat kampung masigi, karena pisang memiliki banyak makna simbolis. Mungkin faktor inilah mengapa panrita dahulu memilih pisang sebagai hidangan dalam ma'barazanji. ${ }^{19}$

Sejak pertama tiba di kampung masigi, wali-wali dahulu mengajarkan Islam kepada masyarakat melalui sentuhan budaya. Hal ini untuk memudahkan mereka agar menerima Islam dengan mudah. Salah satunya dengan menyisipkan pola kebiasaan-kebiasaan masyarakat ke dalam wilayah religius yakni barzanji. ${ }^{20}$

Tanggapan beberapa narasumber di atas memberi kesan bahwa nilai-nilai simbolik yang terdapat pada buah pisang sangat istimewa. Keistimewaan terdapat pada unsur-unsurnya yang semula hanya bentukan dari yang profan, kemudian dengan adanya ulama yang memberikan sentuhan makna spiritual sehingga sifat sakralnya melekat di kalangan masyaraka hingga saat ini.

\section{b. Teks Barzanji}

Sebagian besar pembaca teks barzanji dipandang sakral dalam segenap aspeknya. Unsur-unsur sakralitas tersebut antara lain terdapat pada: Pertama, aspek isinya. Kedua, aspek lafaz yang digunakannya. Ketiga, sikap pembacanya. Keempat, pengalaman esoterisnya. ${ }^{21}$ Dari aspek isi, barzanji mengandung uraian tentang sejarah hidup Nabi Muhammad saw., serta ketinggian dan kemuliaan akhlak beliau. Dari aspek lafaznya, barzanji menggunakan kalimat yang indah dengan nilai susastra yang tinggi, sehingga pembaca yang mampu memahaminya

\footnotetext{
${ }^{18}$ Wawancara via handphone dengan Ust Yasin, salah satu tokoh agama. pada tanggal 20 April, 2019.

${ }^{19}$ Wawancara via handphone dengan Abd. Waris, tokoh masyarakat, pada tanggal 20 April 2019.

${ }^{20}$ Wawancara via handphone dengan Abd. Hamid, tokoh masyarakat, pada tanggal 15 April 2019.

${ }^{21}$ Umar Bukhory, Tradisi Membaca Syair Arab Masyarakat Muslim Pamekasan: Studi Estetika Resepsi atas Barzanji dan Burdah di Pondok Pesantren, Disertasi, h. 106.
} 
dapat menikmati hal tersebut, dengan cara melagukannya dengan irama yang indah. Dari aspek pembacanya, dianjurkan bagi pembacanya untuk berada dalam keadaan suci dari najis dan hadas kecil maupun besarm serta menutup aurat. Adapun dari pengalaman esoterisnya, bahwa berdasarkan keyakinan pembaca untuk mendapatkan pahala dari Allah, lahirlah sikap produktif untuk beramal demi kehidupan akhirat.

Sisi sakralitas barzanji sebenarnya terletak pada isinya yang mengandung sejarah hidup Rasulullah saw., perjuangan beliau dan ahwal lainnya. Karena status beliau sebagai pesuruh Allah dan panutan bagi kebenaran hidup umatnya. Apalagi, tidak semua orang bisa membacanya dengan lagu atau irama yang bagus. Hanya pada orang yang berjiwa seni dan paham ilmu sastra Arab yang dapat membacanya dengan khusyu'. ${ }^{2}$

Sisi sakralitas juga terdapat dalam segi lafaznya yang banyak mengandung nilai sastra, terutama dalam pemahamannya. Maka orang yang membacanya pun merasakan kenikmatan atas apa yang dibaca, kendati para pembaca belum tentu memahaminya secara keseluruhan. ${ }^{23}$ Sisi sakralitas juga dirasakan pembaca dari keyakinan mendapatkan pahala, saat mendengar dan membacanya, dimana ketika shalawat dibacakan dan di dalamnya nama Rasulullah disebut, maka si pendengar harus juga menjawabnya (bershalawat juga). Karena jika tidak, maka dia akan disebut sebagai orang yang kikir, sehingga mereka yang bershalawat dengan menggunakan bahasa Arab, namun tidak paham apa yang dibacanya, diyakini tetap mendapatkan pahala dari Allah, karena memuji keagungan dan kemuliaan Rasulullah, serta kegembiraan dengan kehadiran Nabi saw. ${ }^{24}$

Para pembaca menyebutkan, sakralitas syair barzanji terdapat pada kandungan isi, lafadz, dan bait-bait syairnya secara formal, maka pada posisi inilah

${ }^{22}$ Wawancara via handphone dengan Arief Aziz salah satu pelaku praktek tradisi barzanji, pada tanggal 18 april 2019.

${ }^{23}$ Wawancara via handphone dengan Muhammad Arsyad salah satu pelaku praktek tradisi barzanji, pada tanggal 18 april 2019.

${ }^{24}$ Wawancara via handphone dengan Danial Aziz salah satu pelaku praktek tradisi barzanji, pada tanggal 18 april 2019. 
fungsi informatif dari teks syair tersebut muncul. Karena ada kandungan kata yang memuat pesan tertentu sekaligus menjadi pedoman yang dapat memenuhi kebutuhan semantis pembacanya secara personal akan dimensi sakralitas tersbut.

\section{c. Ketokohan Ulama}

Menggambarkan status annangguru ${ }^{25}$ di tengah masyarakat, diartikan sebagai tempat atau posisi seseorang dalam suatu kelompok sosial. Sedangkan kedudukan sosial (social status) artinya tempat seseorang secara umum dalam masyarakat sehubungan dengan orang lain, dalam arti lingkungan pergaulan, prestise, hak dan kewajibannya. Namun untuk mempermudah dalam pengertiannya maka dalam kedua istilah di atas akan dipergunakan dalam arti yang sama dan digambarkan dengan istilah "kedudukan" (status) saja. ${ }^{26}$

Masyarakat pada umumnya mengembangkan dua macam kedudukan (status), yaitu sebagai berikut: Pertama, ascribed status yaitu kedudukan seseorang dalam masyarakat tanpa memerhatikan perbedaaan rohaniah dan kemampuan. Kedudukan ini diperoleh karena kelahiran. Kedua, achieved status yaitu kedudukan yang dicapai oleh seseorang dengan usaha yang disengaja. Kedudukan ini bersifat terbuka bagi siapa saja, tergantung dari kemampuan masing-masing dalam mengejar serta mencapai tujuannya. Kadang-kadang dibedakan lagi satu macam kedudukan, yaitu assigned status, merupakan kedudukan yang diberikan. Status ini sering berhubungan erat dengan achieved status, dalam arti bahwa suatu kelompok atau golongan memberikan kedudukan yang lebih tinggi kepada seseorang yang berjasa telah memperjuangkan sesuatu untuk memenuhi kebutuhan dan kepentingan masyarakat. ${ }^{27}$ Kedudukan annangguru berada pada ascribed

${ }^{25}$ Annangguru merupakan bentuk panggilan kepada orang-orang yang memiliki keahlian dalam bidang agama serta dianggap mampu merepresentasikan cita rasa lokal tanpa kehilangan ciri sebagai seorang ulama Penggunaan kata ini hanya digunakan untuk daerah Campalagian dan Pambusuang yang dikenal sangat kental dengan kerakter kereligiusannya khususnya pengajian kitab kuning.

${ }^{26}$ Aco Musaddad, Annangguru dalam Perubahan Sosial di Mandar (Polewali Mandar: Gerbang Visual, 2018), h. 159-160.

${ }^{27}$ http://www.scribd.com/doc/13055094/makalah-sosiologi-perannorma. 18/05/2019. 
status dan achieved status, yang diperoleh sejak lahir sekaligus diusahakan mencapai kedudukan tersebut.

Peran tersebut ia duduki sesuai dengan statusnya atau kedudukannya di tengah masyarakat, yakni berkedudukan sebagai, muballig, Pimpinan Pesantren dan pengajian kitab serta annangguru berkedudukan sebagai konsultan supranatural dan spiritual. Masalah tarekat, annangguru mempunyai peran tersendiri di tengah masyarakat. ${ }^{28}$

Berdasarkan peran dan posisi annangguru di atas, pada kenyataannya di masyarakat memberikan efek kepada simbolisasi dalam ruang publik maupun spiritual. Pengaruh-pengaruh islamisasi yang berhasil ditransformasikan melalui sentuhan budaya dan agama, memberikan pengaruh yang signifikan bagi status ulama di mata masyarakat. Hal inilah yang memperkuat melekatnya sifat-sifat religiusitas terhadap annangguru melalui upaya simbolisasi sebagimana dalam praktek barzanji di Masjid Raya Campalagian dengan ketokohannya yang dianggap sakral.

\section{d. Malam Jum'at}

Unsur-unsur kesakralan tidak hanya lahir dari ketiga aspek di atas. Sebagaimana kebiasaan masyarakat kampung masigi, mereka mempunyai waktuwaktu tertentu yang dianggapnya memiliki nilai suci atau keistimewaan di dalamnya. Hal ini tergambar pada pelaksanaan tradisi barzanji di Masjid Raya Campalagian yang dilaksanakan pada malam jum'at.

Kehadiran waktu malam jum'at diyakini sebagian masyarakat sebagai momentum untuk menjalin silaturrahim antara masyarakat. Kahadirannya yang dibarengi dengan tradisi barzanji, memperkuat sisi kesakralannya di kalangan masyarakat. Menurut salah satu informan menyatakan bahwa; malam jum'at

\footnotetext{
${ }^{28}$ Wawancara via handphone dengan Abd. Waris, tokoh masyarakat, pada tanggal 20 april 2019.
} 
merupakan malam yang mulia, dimana banyak peristiwa-peristiwa besar terjadi dan di dalamnya terdapat kemuliaan dan keberkahan. ${ }^{29}$

\section{Barzanji sebagai Ekspresi Keberislaman dalam Upaya Pelestarian Sunnah}

Tradisi barzanji bisa dikatakan sebagai ibadah yang sifatnya sunnah dalam kacamata kultural studies karena terdapat berbagai alasan yang melatarbelakanginya, misalnya saja: Pertama, meningkatkan semangat kecintaan dan pengamalan nilai kesalehan kepada Nabi Muhammad saw. sebagai uswatun hasanah yang patut dicontoh oleh masyarakat masa kini. Dalam hal ini, terdapat transfer nilai-nilai luhur yang bisa diambil dari sosok Nabi sendiri untuk bisa diamalkan dalam kehidupan sehari-hari. Kedua, merekatkan ukhuwah islamiyah di antara umat muslim karena pergelaran bazanji sendiri selalu melibatkan banyak orang dan massa melihatnya juga banyak sehingga di samping mendapatkan nilai edukasi dari pembacaan tradisi barzanji serta meningkatkan interaksi antar sesama masyarakat. Ketiga, meningkatkan amalan ibadah tertentu bagi individu yang senantiasa membaca barzanji di setiap waktu senggangnya karena barzanji secara langsung menuntun seseorang untuk mengamalkan salah satu poin dalam rukun iman yakni kepada Rasul dan Nabi Allah. ${ }^{30}$

Secara garis besar, barzanji sebagai ritus budaya memang berkembang pesat di kalangan pesantren, kalangan nahdlyyin, kalangan Islam tradisionalis, maupun kalangan Islam kejawen. Hal ini dikarenakan tradisi barzanji sebagaimana dengan tradisi lainnya secara umum merupakan bentuk dari ajaran syiah kultural yakni menghormati dan mengenang peran dan jasa Nabi Muhammad saw., shahabat, dan keturunannya yang berjasa menyebarkan Islam sebagai agama rahmatal lil alamin kepada semesta dalam bentuk ekspresi kebudayaan maupun produk budaya. Dalam sebuah hadits disebutkan bahwa pembacaan barzanji sebagai wujud cinta kepada Rasul merupakan kewajiban bagi semua umat Islam.

\footnotetext{
${ }^{29}$ Wawancara via handphone dengan Danial Aziz salah satu pelaku praktek tradisi barzanji, pada tanggal 18 april 2019.

${ }^{30}$ Ahmad Ta'rifin, Tafsir Budaya atas Tradisi Barzanji dan Manakib. Jurnal Penelitian. Volume 7. Nomor 2, 2010, h. 2.
} 
Sebagaimana tersebut dalam sebuah hadits Nabi: "Tidak sempurna iman seseorang sehingga aku menjadi orang yang paling dicintainya dari pada anaknya, orang tuanya dan manusia semuanya" (HR. Bukhari). ${ }^{31}$

Hal inilah yang menjadikan alasan barzanji hidup dan berkembang di kalangan Islam tradisionalis, khususnya apa yang telah mentradisi di kalangan masyarakat kampung masigi, karena semata-mata hal itu merupakan bentuk sunnah bahwa melestarikan tradisi Nabi adalah baik disesuaikan dengan ajaran alQur'an dan Hadits sehingga tidaklah relevan kalau menyebut barzanji itu menyimpang karena itu sudah ada sejak zaman Nabi dan diperbolehkan oleh Nabi sendiri sebagai bentuk ekspresi budaya untuk mencintai Allah dan Rasul-Nya. Maka dari itulah, upacara pembacaan barzanji merupakan ritus religius dan dimaksudkan untuk ibadah yakni taqarrub ilallah yakni menjalin hubungan dekat dengan Allah SWT untuk mendapatkan ridha-Nya. ${ }^{32}$ Tradisi barzanji sebagai produk budaya kuasa kalangan tradisionalis lebih mengajak pada pengamalan ajaran Islam melalui dimensi nyata kehidupan sosialnya yang tidak hanya terpaku pada ajaran leksikal al-Qur'an dan Hadis saja yang bagi sebagian umat sangatlah kaku dan konservatif sehingga melalui tradisi barzanji maupun tradisi lainnya yang berkembang pada zaman Nabi, kedua tradisi tersebut dikontekstualisasikan melalui ekspresi budaya. Dan bagi kalangan tradisionalis itu adalah bagian dari sunnah karena mengamalkan ajaran Islam dalam keseharian.

\section{Kesimpulan}

Setelah melakukan penelitian, memaparkan data dan melakukan analisis secara seksama, maka peneliti dapat memberikan kesimpulan sebagai berikut:

1. Bahwa tradisi banrzanji yang dilaksanakan pada malam jum'at di Masjid Raya Campalagian terkandung simbol-sombol yang melekat di dalamnya unsur-unsur sakralitas. Aspek-aspek sakral ini melekat pada buah-buahan

\footnotetext{
${ }^{31}$ Wawancara via handphone dengan Ust Yasin, salah satu tokoh agama. Pada tanggal 20 april, 2019.

${ }^{32}$ Wawancara via handphone dengan Arief Aziz salah satu pelaku praktek tradisi barzanji, pada tanggal 18 april 2019.
} 
seperti pisang, mangga, rambutan, teks barzanji, ketokohan ulama, dan waktu pelaksanaannya (malam jum'at).

2. Secara umum, terdapat dua fungsi simbol-simbol yang ditampilkan pada praktek tradisi barzanji tersebut: a). Fungsi normatif; meningkatkan semangat kecintaan dan pengamalan nilai kesalehan kepada Nabi Muhammad saw. sebagai uswatun hasanah yang patut dicontoh oleh masyarakat sehingga nilai-nilai luhur yang melekat pada diri Nabi saw. dapat tersalurkan dalam kehidupan sehari-hari, meningkatkan amalan ibadah tertentu bagi individu yang senantiasa membaca barzanji di setiap waktu senggangnya karena barzanji secara langsung menuntun seseorang untuk mengamalkan salah satu poin dalam rukun iman yakni kepada Rasul dan Allah. b). Fungsi humanis; merekatkan ukhuwah islamiyah di antara umat muslim karena pergelaran barzanji sendiri selalu melibatkan banyak orang dan massa melihatnya juga banyak sehingga di samping mendapatkan nilai edukasi dari pembacaan tradisi barzanji serta meningkatkan interaksi antar sesama masyarakat.

\section{DAFTAR PUSTAKA}

Abdurrahman, Masykuri, Burdah Imam al-Bukhari; Kasidah Cinta dari Tepi Nil untuk Sang Nabi. Pasuruan: Pustaka Sidogiri, 2009.

Allen, Roger, An Introduction to Arabic Literature. Australia: Cambridge University Press, 2003.

Bruinessen, Martin van, Kitab Kuning, Pesantren dan Tarekat; Tradisi-tradisi Islam di Indonesia. Cet.III; Bandung: Mizan, 1999.

Bukhory, Umar, Tradisi Membaca Syair Arab Masyarakat Muslim Pamekasan: Studi Estetika Resepsi atas Barzanji dan Burdah di Pondok Pesantren, Disertasi . Yogyakarta: Pascasarjana UIN Sunan Kalijaga, 2018.

Eliade, Mircea, Pattern in Comparative Religion, Rosemary Sheed trans. New York: The University of Nebraska Press, 1996.

----------, The Sacred and the Profane; the Nature of Religion. New York: A Harvest Books,t.t.

http://www.scribd.com/doc/13055094/makalah-sosiologi-perannorma. $18 / 05 / 2019$.

Ismail, Arifuddin, Unsur-Unsur Islam dalam Ritual Nelayan Mandar di Pambusuang Kab. Polewali Mandar Sulawesi Barat. Dalam Majalah Walasuji vol 5, No. 2, Desember 2014. 
Manshur, Fadlil Munawwar, "Polemik Pemaknaan Kasidah Burdah al-Bushiry: Kajian Estetika Negatif", Jurnal Adabiyyat, vol. xi, no, 2, Desember 2012. Musaddad, Aco, Annangguru dalam Perubahan Sosial di Mandar. Polewali Mandar: Gerbang Visual, 2018.

Pals, Daniel L., Seven Theories of Religion; Tujuh Teori Agama Paling Komprehensif, Inyiak Ridwan Muzir \& M. Syukri terj. Cet. II; Yogyakarta: IRCiCoD, 2012.

Rasmussen, Anne K., Women, the Recited Qur'an and Islamic Music in Indonesia. California: University of California Press, 2010.

Ratna, Nyoman Kutha, Antropologi Sastra; Peran Unsur-unsur Kebudayaan dalam Proses kreatif. Yogyakrata: Pustaka Pelajar, 2011.

Sunarti, Sastri, Kosmologi Laut dalam Tradisi Lisan Orang Mandar di Sulawesi Barat, Jurnal Aksara vol 29, No. 1, Juni 2017.

Suryadilaga, M. Alfatih, "Model-model Living Hadis" dalam Sohiron Syamsuddin (ed.) Metodologi Penelitian Living Qur'an dan Hadis. Yogyakarta; TH Press, 2007.

Ta'rifin, Ahmad, Tafsir Budaya atas Tradisi Barzanji dan Manakib. Jurnal Penelitian. Volume 7. Nomor 2, 2010. 